\title{
THE ROLE OF DESTINATION MANAGEMENT COMPANIES (DMC) IN IMPROVING COMPETITIVENESS OF SERBIA AS A TOURISM DESTINATION
}

\author{
Vesna Spasić, Danijel Pavlović* \\ Singidunum University, Faculty of Tourism and Hospitality Management, 32 Danijelova St., Belgrade
}

\begin{abstract}
:
Turbulent changes in the tourism value chain, especially in distribution chains of tourism products and services, have created conditions for intensive activities and have triggered the new role of incoming travel agencies, and led to the emergence of destination management companies (DMC). This new type of travel agencies (DMC) is oriented towards a wider range of activities within the destinations and assumes an important role in creating more complex products. The aim of this paper is to indicate possible positive effects of DMC on tourism destination development, and particularly, enhanced competitiveness of Serbia as a tourism destination. So far, such contribution of DMCs in our country can be visible in the area of the so-called MICE tourism (meetings, incentives, conferencing, exhibitions). Owing to the DMC activities, positive effects could be achieved by offering new tourism products. This paper starts with the evaluation of previous trends related to the activities of domestic incoming agencies and highlights the necessity for strengthening the role of DMC based on the collaboration between the private and the public sector.
\end{abstract}

\section{Key words:}

Destination Management Companies (DMC),

tourism development, destination competitiveness, Serbia.

\section{INTRODUCTION}

Turbulent changes in the tourism value chain, triggered by constant innovations and the Internet technology, especially in distribution channels of tourism products, have created necessary conditions for the new quality role of incoming travel agencies. Fundamental changes are primarily visible in abandonment of conventional role of ground operators. Traditionally, they operated within the destination dominantly as intermediaries between service providers at the destination and tour operators from generating tourism and travel markets, providing simple services such as: transfers, meet-and-greet at airports, local excursions etc. The expansion of the Internet and information and communication technologies has encouraged new approach to generating markets, and created new possibilities for service providers within the destination. At the same time, tourists emerge more and more as individual travellers who are organizing their travel independently using different tools available on the Internet. The individualization of tourist demand, and tendency towards development of direct sales channels by different service providers in tourism and travel industry, has threatened the basic intermediary role of traditional travel agencies and led to the process called the "Reintermediation phase" (Cheung \& Lam, 2009; Spasić, Pavlović \& Stanić, 2015). These tendencies were particularly intensive in the US market at the beginning of the 21st century, and have also emerged on developed tourism and travel generating markets of European countries (Great Britain, Germany) (Beiderman, 2008; Holloway, 2004; Buhalis, 2003).
Along with the process of elimination of travel agencies as traditional intermediaries, new types of intermediaries - online agencies (OTA), have emerged. They based activities on the Internet which brought about new possibilities in communication with consumers and services providers in the travel and tourism industry. In addition, a new part of incoming travel agency activities has shown a positive trend. These are the activities that can be emphasised as part of the process of strengthening the DMC role.

This research is primarily focused on the Serbian tourism market. The analysis is based on the effects that domestic travel agencies have on attracting foreign tourists and providing services throughout their stay. Difficulties in the analysis stem from the fact that there is no extensive research that provides more accurate data on the structure of foreign tourist expenditure in Serbia. Also, there are no precise data on the share of travel agencies in the distribution of different products and services. The initial step in the analysis is based on the available statistics, obtained from the Statistical Office of the Republic of Serbia, on foreign tourists who visit Serbia using the services of domestic travel agencies. Based on the statistical data, we come to the conclusion about the trends during the period from 2007 to 2013. These data provide only a partial basis for assessing the role of travel agencies, and in support of that, we shall highlight several conclusions:

- Incoming agencies offer is directed towards all segments of tourists coming to the country (individually or organized by foreign tour operators, cruise lines, travel agencies, meeting planners etc.), and includes a set of different products and services. Accordingly, 
the effects are far greater than it could be assessed based solely on the role in attracting foreign tourists and providing them with accommodation services.

- The analysis based only on the number of visitors and the number of overnights stays, does not provide a reasonable basis for the adoption of appropriate conclusions. The effects can be analysed only on the basis of the analysis of foreign tourists' expenditure and distribution of complex and innovative products.

For these reasons, the next step in the research was the analysis of the existing travel agencies offer intended for foreign tourists. The analysis was conducted on the basis of the current offers available on the websites of the travel agencies, that according to YUTA classification belong to the group of incoming tour operators in Serbia (YUTA). This group includes 27 travel agencies.

In this paper, we shall attempt to estimate the next phase in DMC development in Serbia and their orientation to different segments of leisure travel. We shall also to try to determine whether there are few isolated examples of real domestic DMC in Serbia that struggle for the position on the international tourism market. This is a necessary step because without quality incoming agencies that assume the role of DMC, there are no basic conditions for the achievement of significant economic effects of tourism in a country.

\section{THE TERM AND ROLE OF DMC}

A destination management company is a professional management company specializing in the design and delivery of tours, events, local transportation and other different activities based on local knowledge and expertise. This type of company is locally- based and uses local resources to provide products and services and satisfy interests and needs of individual clients and groups within a specific city, region or a country. Its local knowledge and experience allows designing products for clients such as: outgoing travel agencies and tour operators, meeting planners and other event organizers, as well as for independent travellers at the destination (USAID, 2015, p. 5; ISMP, 2015; ADMEI, 2015).

The term "Destination Management Company" emerged in the USA as a result of the expanded role of this type of agencies. Ground operators (incoming or handling agencies) were usually small local enterprises providing basic services such as, transfers, meet-and-greet at airports, local excursions and different kinds of sport and recreational activities. In the beginning, DMC started to add numerous new products and services as local experts and they were primarily oriented towards business travellers (organization of congresses and other types of meetings, incentive programs, organization of different business events etc.). The next step was their orientation towards leisure travellers when they started to offer complex and specialized products.

Modern DMC are characterized by complex activity, more sophisticated products and more independent market approach. Some of them took over the role of incoming tour operators, specializing in a specific destination and creating products for unknown customers. DMC are developing appropriate distribution channels by using the advantages of the Internet communication. Online channels are used for direct sales to individual customers. On the other hand, they also make more complex distribution channels based on the creation of network with tour operators, travel agencies, meeting planners and other companies from generating markets.

The growing experience of potential tourists in mature tourism and travel generating markets and their readiness for organizing holidays based on the principle "do-it-yourself" is an important factor for incentive DMC. Tourists show a high level of trust towards agencies within the destination that have precise knowledge and information about the resources and the overall situation within the destination. Also, a stimulating factor for strengthening the role of DMC in the distribution channels comes from social networking in destinations with special benefits for service consumers. On the contemporary tourism market, such effects are particularly present in the field of MICE tourism, but also in the whole range of leisure programmes.

\section{THE ASSESMENT OF BUSINESS TRENDS IN THE INCOMING AGENCIES IN SERBIA}

The development of incoming travel agencies in Serbia is in the initial stage and positive effects have so far been achieved in the field of MICE tourism. According to ICCA 2014 Country \& City rankings, Serbia assumes the 46th place among the top 50 destinations worldwide, based on destinations' meetings-related performance on a global scale (SCB, 2015). Data providers for this ranking are hotels, venues, travel agencies, transport companies and other service providers.

According to the National Tourism Organisation of Serbia, there are 30 travel agencies in Serbia oriented towards congresses and other forms of MICE tourism, with different size and market position (TOS). Some of them are organized as DMC and have achieved certain level of success in promoting and selling their products in the international market (Spasić, Njeguš \& Pavlović, 2014).

In order to attempt to assess the role of domestic incoming agencies, we have used available statistical data. The data are used for the comparative analysis of trends in foreign tourist arrivals and overnight stays in Serbia realized by domestic travel agencies for the period from 2007-2013. The results are shown in Table 1.

Table 1. Foreign tourist arrivals and overnight stays, 2007-2013

\begin{tabular}{ccccc}
\hline Year & $\begin{array}{c}\text { Total } \\
\text { arrivals }\end{array}$ & $\begin{array}{c}\text { Total } \\
\text { nights }\end{array}$ & $\begin{array}{c}\text { By domes- } \\
\text { tic travel } \\
\text { agencies - } \\
\text { arrivals }\end{array}$ & $\begin{array}{c}\text { By domes- } \\
\text { tic travel } \\
\text { agencies - } \\
\text { nights }\end{array}$ \\
\hline 2007 & 696.000 & 1.476 .000 & 34.034 & 87.950 \\
\hline 2008 & 646.000 & 1.399 .000 & 32.487 & 76.449 \\
\hline 2009 & 646.000 & 1.469 .000 & 27.726 & 59.378 \\
\hline 2010 & 682.681 & 1.452 .156 & 23.794 & 68.765 \\
\hline 2011 & 764.167 & 1.643 .054 & 21.648 & 56.398 \\
\hline 2012 & 809.967 & 1.796 .217 & 20.139 & 56.522 \\
\hline 2013 & 921.768 & 1.988 .393 & 21.449 & 62.432 \\
\hline
\end{tabular}

Source: Statistical office of the Republic of Serbia, Statistical Yearbook, 2008-2014 
During the period from 2007-2013, negative trends are observed in the number of foreign tourists coming to our country, organized by domestic travel agencies; During the observed period, the number of visitors arrivals via agencies decreased by $159 \%$, whereas the number of overnight stays decreased by $141 \%$. A slight increase was recorded in the last observed year (2013), when 21.449 foreign visitors came to Serbia via agencies ( $+6.5 \%$ compared to 2012$)$ and generated 62.432 overnight stays $(+10.4 \%)$. Predominantly negative trends can be observed compared to the results of the overall number of foreign tourists during the reporting period: the number of total visitors increased by $32.4 \%$ and the number of overnight stays by $34.7 \%$; That led to a drop in relative participation of travel agencies in bringing foreign tourist from $4.9 \%$ in the number of visitors and $6 \%$ in the number of overnight stays in 2007 , to $2.3 \%$ in the number of visitors and 3.1\% in the number of overnight stays in 2013. The important fact is connecting with the average length of stay: foreign tourists coming via domestic travel agencies stay longer (2.9 days) compared to the results in the overall foreign tourism turnover ( 2.2 days based on the data in 2013).

Changes in the number of arrivals and overnight stays of foreign tourists are shown in Figure 1.

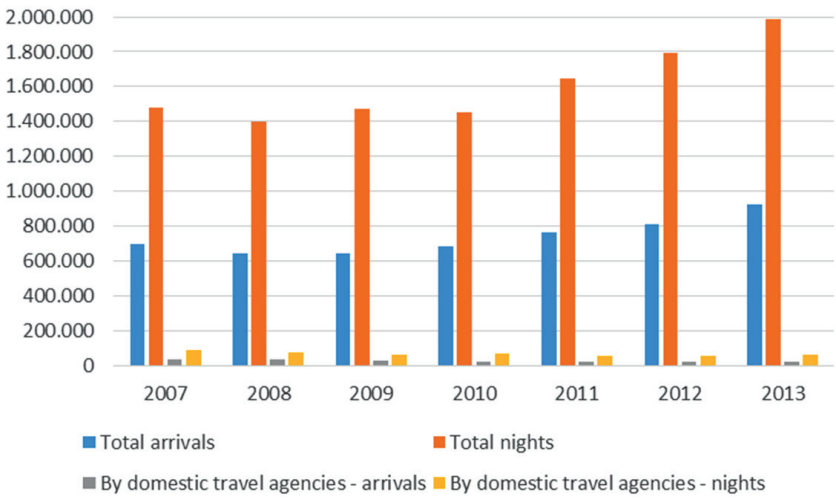

Figure 1. Foreign tourist arrivals and overnight stays, 2007-2013 - by domestic travel agencies

The aim of qualitative analysis of the group comprising 27 incoming tour operators, the members of YUTA (National association of travel agencies of Serbia), is the evaluation of the complexity of products and services that include Serbia as a tourist destination, as well as the degree of orientation towards international markets. The analysis is based on the current products and services available on the official sites of agencies, bearing in mind the necessity of websites as an instrument of modern communication with the global market.

The analysis started from some basic questions.

Do agencies use web sites for promotion and selling purposes? The analysis of websites indicates that the answer is negative for 2 agencies (they don't use the possibility of presentation by web site), while for one another agency, it could be observed that the web site is in the process of renovation.

Are the web sites used as an instrument of communication with business partners and individual tourists from foreign markets? The answer is positive in the case of 9 incoming tour operators that also have presentations of their offer in English (30\% of the total number of tour operators in the particular group). Further analysis indicates that only 3 tour operators (Magelan, Glob Metropoliten Tours and Eurojet - with 2 brands focused towards incoming tourism: SerbiaIn and Go2Serbia) have presentations in 3 or 4 languages.

The particular group of 9 incoming tour operators, having presentation in English, is the subject to further analysis. Tour operators based in Belgrade (6) dominate in the group, followed by Novi Sad (2), while one tour operator has its headquarters in Uzice.

The products of MICE tourism are represented by almost all tour operators from the observed group. In addition, the products of agencies in this group are focused on leisure market: classic tours (Balkan tours, as well as tours that include only Serbian destinations), city breaks and sightseeing tours. The products are given in a form of guaranteed tours, suggested tours, as well as the possibility of creating tailor-made products, while a number of tour operators (3) have special brochures focused on international market, which can be downloaded from the site.

Some incoming tour operators create innovative products, such as special tours, for instance "Rafting on the Tara river", "Bird watching", Roads of rakia and raspberry, Cruising on Serbian rivers, trips that include a variety of events - concerts, festivals, sports events etc.

An important question for our study is related to whether there are agencies whose operations have characteristics of DMC operations. Magellan and Bon Voyage, the agencies from Novi Sad, declared their operations as the business of DMC, but complexity of created products and services, as well as the way of presentation focused on the international market, led the authors to the conclusion that Glob Metropoliten Tours can be included in this group. Magellan emphases its leading position as DMC in Serbia that annually provides 3000 foreign tourists in Serbia (Turistički cvet, 2015).

The research leads to the conclusion that domestic tour operators that "declare" as incoming, are not focused on international market, and that, with a few noted examples, we can state that only initial steps have been taken in positioning of DMC on the leisure market and that we can expec intensive activities in the future.

\section{THE NECESSITY OF STRENGTHENING THE ROLE OF DMC IN IMPROVING COMPETITIVENESS OF SERBIA AS A TOURISM DESTINATION}

Without incoming agencies that seriously take the role of DMC, it is not possible to realize significant economic effects in the Serbian tourism market, especially, having in mind the necessity for redirecting tourism flows to relatively unknown destinations in the country. It is well-known that Belgrade is the leading incoming destination in Serbia and that the processes of activating other destinations and involving them in programs for foreign tourists would be an important task for DMC.

A significant part of potential tourism demand will not turn into reality without stimulating the role of travel agen- 
cies. In support of this thesis stands the fact that, in global tourism market, the role of tour operators and travel agencies increased in the case of including new and unknown destinations in the market, and particularly if there are significant difficulties in connecting the destination with the most important generating countries. When it comes to complex package tours, travelling from distant source markets, especially those associated with a high degree of risk, the role of tour operators and travel agencies is far more important since higher number of users choose organized tours as opposed to the number of tourists who opt for individual travel. The breakthrough into the distant markets such as, for instance, Chinese, is impossible without various forms of cooperation between tour operators and agencies. In addition, the trends towards more individualized travel, reliability, security and guarantee of quality, when they represent the hallmark of tour operators business, can be the supporting factors for potential tourists in making decisions about buying travel packages. In the tourism value chain, DMC occur as an irreplaceable link to the destination, especially in providing a range of services to individual tourists and tourist groups. Their considerable knowledge about destinations and connections with various participants on the side of tourism supply, enable them to create and deliver high-quality products at the lowest cost. Foreign tour operators need quality DMCs that are, on the other hand, reliable partners in servicing tourist groups at the destination.

The distribution of tourism products and services is one of the crucial factors for successful positioning of destinations in the international market. It is important to establish effective channels connecting the supply and demand. On the other hand, supply is sometimes trying to eliminate intermediaries, not realizing their key benefits: better knowledge of travel and tourism generating markets, cover of a wider potential market, successful market communication and lower total marketing costs. For enterprises on the side of tourism supply, a distinct advantage of agencies and tour operators, as part of distribution channels, is particularly apparent when the supply is higher than demand. Through its activities, tour operators and travel agencies can make a positive contribution to the extension of the tourist season in tourist destinations. Development of correct relationships is a condition of mutually beneficial and long-term cooperation based on the positive economic effects for both sides.

In the upcoming period, conditions for intensifying the role of DMC should be created. The role of the DMC in organization of different activities, especially those connected to the enrichment of the activities for tourists, indicates their importance in contribution to the improvement of tourist destinations competitiveness, tourist expenditure and foreign exchange earnings. DMCs activities contribute to the quality of the products offered in the destination and also its activities contribute to the destination competitiveness at the international market. These companies can use their considerable knowledge about destination attractiveness, and detection of unknown destination resources, to create new products, which can lead to increased consumption. In this way, they attract new market segments and create added value on the destination product. The inclusion of, so far, insufficiently activated attractiveness into the tourist product and, particularly, the extension of the tourist season can significantly contribute to better utilization of already built accommodation capacities in certain destinations. In rural tourism in Serbia, accommodation capacity utilization is only 4\% (UNWTO, 2011). Activation of the available natural and man-made tourist attractions and better utilization of accommodation capacities would be a chance for greater employment of rural population and rural areas development. In such a way, the DMC could achieve a stimulating role in the overall more balanced regional development of Serbia.

The possibility for product and services delivery to foreign tourists should be seen as part of contemporary tendencies in the Serbian market and potential benefits that arise for local agencies. In recent years, intensive crisis in the travel agencies activities in Serbia could be observed, and therefore, there is a need for new strategies that will lead to improvement of the competitive position. This is
POSITIVE

- Expert knowledge of available resources in the domestic market.

- Relatively well-developed DMC operations in the field of MICE tourism

INTERNAL

EXTERNAL - The possibility of forming new products (e.g. Wine tours, adventure trips, bike tours etc.).

- The available natural and built resources inside the country.

- Advantages of modern technology that enable presence on the global market at low cost.
- The increasing interest for Serbia as a tourism destinakey).

- The emergance of new market segments and increase in demand in the field of tourism of special interests.
NEGATIVE

- The agency business is dominated by small businesses that do not have the means for a significant orientation towards foreign markets.

- Lack of qualified staff with good knowledge of foreign markets.

- Lack of interest in local agencies for receptive business.

- Lack of cooperation with representatives of the public sector at the destination.

- Unwillingness of certain part of tourist offer to cooperate with DMC.

- Lack of adequate capacity, in terms of volume and quality in some areas.

- Undeveloped transport infrastructure and the unavailability of certain tourism sites.

- Lack of quality destination management at many destinations in Serbia.

- Lack of professionalism in the work of the public sector in particular local communities and lack of willingness to cooperate with local agencies.

- Lack of interest of certain part of tourism offer to cooperate with DMC. 
based on the estimations of the world's leading analysts who estimate that future intensification of global competition with the further expansion of large multinational companies should be expected. Although still at an early stage, these processes are already present on the Serbian market, primarily the growing trend of direct booking and purchasing via the Internet. In addition, the leading German tour operators, TUI and DerTour, have been present on the Serbian market for several years. In conditions of the growing global competition in tour operators and travel agencies business, we should consider that besides global mega companies, local agencies that are well-familiar with the market and can specialize in offering a range of attractive products at the destination, will have a significant role in the future (UHPA, 2011).

Despite the present trend with an emphasis on travel individualization, numerous studies in Serbia show that the role of the DMC should not be viewed only in organizing more attractive stay for tourists, but also in the fact that its activity can contribute to resolving some of the current difficulties foreign tourists face at the destination. The fact is that certain segments of public transport in the country are almost completely undeveloped and there is no possibility of access to most tourist attractions in the interior of Serbia using the public transport. Difficulties for domestic and foreign tourists also appear due to the lack of traffic and tourist signs. The absence of high-quality and experienced guides, with the possibility of interpretation in several languages, is one of the deficiencies of Serbia's tourist offer. Creation and implementation of new programs that should include the interior of the country would have great benefits for tourists, and with the exception of Belgrade and Novi Sad, Serbia represents an undiscovered destination in the European and global market. All this indicates that there are significant opportunities for DMC in the domain of creation and selection of quality products that can affect the competitiveness of Serbia as a tourism destination.

In accordance with these observations, Fig. 2 shows the SWOT analysis of DMCs in Serbia.

The realization of the potentially significant role of DMC in improving Serbia's competitiveness as a tourism destination, is possible under the condition that the growing number of travel agencies focus on creation of new complex products, for the purpose of discovering new and undeveloped tourist sites, inclusion of the local population and their products into the programs that offer authentic products and apply the principles of sustainable tourism development instead of mass tourism products.

\section{SUMMARY}

By analysing the available programs that were the subject of this research, it can be concluded that there is no directing of the receptive agencies to two important strategic directions for future development of Serbia, namely the tourism of special interests and event organization.

The special benefits of DMC can be achieved in products intended for tourists with special interests. Dynamic changes in modern tourists' demands, with the appearance and narrow market niche, can be the basis for specialization and authentic quality products based on the available resources where Serbia has numerous comparative advantages. An abundance of opportunities can be found in offering a wide range of new and authentic products, among which we can allocate certain products that can already be observed with the initial positive results, such as wine tours or bicycle tourism.

Another potentially significant product group are events that according to the Serbian Tourism Strategy are marked as the so-called Quick win products. Not taking the opportunity to note the quality of many events that take place in Serbia, may indicate only the lack of professionalism in the organization, and the consequences are minimal effects in attracting domestic and foreign tourists. One of the important activities of modern DMC worldwide refers to a variety of events, and this professional role exists in Serbia only in the field of MICE tourism. It is obvious that the professional role of DMC in the organization of events aimed at tourism market in Serbia is still pending.

The experience of successful and well-positioned tourist destinations indicates that the quality of complex tourist products based on authentic values and preserved natural and built environment, significantly affects the overall attractiveness of a tourist destination. DMC can only be successful as part of an overall quality destination management based on coordination and joint action of all participants in the area, especially mutual cooperation of the private and public sector.

Cooperation of incoming agencies with various participants from the Serbian public sector is still at the initial phase. Positive examples can be observed for agencies from the region of Belgrade and Novi Sad (Novi Sad Magellan, Glob Metropolitan Tours, and others) and those are usually joint promotional activities at fairs. In general, cooperation can be described as insufficient and receptive agencies are often in a competitive relationship with the local tourist organizations. Public sector contribution is essential in generating market research and joint appearance.

Previous experience has shown that for positioning on the new travel and tourism generating markets, the investments in a period of 2 or more years are necessary until the first positive economic effects appear. Small agencies, that dominate the agency sector in Serbia, have neither financial assets nor enough professional staff necessary to lead long-term programs in order to conquer foreign markets. The coordination and cooperation of all stakeholders in the tourism destinations is also very important, because through product placement, DMC provides a range of other services at the destination (accommodation, meals, sightseeing tours and tourist attractions, services in the field of sport and recreation, entertainment, adventure).

The public sector has a particularly responsible role, whose task is to create conditions for development of private initiatives in the area, and it also represents the basic mechanism in providing necessary cooperation of all participants in destination management. Continuous efforts towards improving the quality of services of all participants in the tourist offer of a destination is also an important task of the public sector, which is based on different aspects of employee education in the tourism sector. Recent experiences in some neighbouring countries (Croatia, Macedonia) have shown that positive effects can be achieved within a relatively short period of time, owing to the support mechanisms aimed directly at receptive agencies that are primarily focused on attracting foreign tourists. 
In the upcoming period, DMC can achieve a competitive advantage when creating new products based on the use of their own knowledge, considerable knowledge referring to available resources in the domestic market, but also the use of new technologies in communication with foreign markets.

\section{REFERENCES}

ADMEI-Association of destination management international. (2015). What is a DMC? Retrieved August 30, 2015, from http://www.adme.org/dmc/what-is-a-dmc.asp

Biederman, P.S. (2008). Travel and Tourism: an industry primer. Upper Saddle River, NJ: Pearson.

Buhalis, D. (2003). eTourism: Information technology for strategic tourism management. Harlow, England: Financial Times Prentice Hall.

Holloway, J.C. (2004). Marketing for Tourism, 4th edition. England: Pearson Education Limited, Essex.

ISMP- International Society of Meeting Planners. (2015). Destination Management Companies: How They Work. Retrieved August 30, 2015, from http://www.ismp-assoc.org/documents/Destination_Management_Companies_\$10.pdf

Ministarstvo trgovine, turizma i usluga Republike Srbije, Horwath Consulting Zagreb i Ekonomski fakultet Beograd. (2005). Strategija razvoja turizma Republike Srbije - Prvi fazni izveštaj. Beograd: Ministarstvo trgovine, turizma i usluga Republike Srbije.

SCB-Serbia Convention Bureau. (2015). Serbia Hits New Record at ICCA Rankings. Retrieved August 29, 2015, from http://www.scb.travel/serbia-convention-bureau/news/ Serbia-Hits-New-Record-at-ICCA-Rankings.n-1.22.html

Spasić, V., Njeguš, A., \& Pavlović, D. (2014). Modern information technologies application in destination management companies, SINTEZA 2014; Impact of Internet on Business activities in Serbia and Worldwide; E-Business in tourism and hospitality industry, pp. 772-776, 2014. DOI: 10.15308/SInteZa-2014-772-776.

Statistical Office of the Republic of Serbia. (2008). Statistical Yearbook of the Republic of Serbia 2008. Retrieved August 25, 2015, from http://pod2.stat.gov.rs/ObjavljenePublikacije/G2008/pdf/G20082003.pdf

Statistical Office of the Republic of Serbia. (2009). Statistical Yearbook of the Republic of Serbia 2009. Retrieved August 25, 2015, from http://istmat.info/files/uploads/47438/ statistical_yearbook_of_the_republic_of_serbia_2009.pdf
Statistical Office of the Republic of Serbia. (2010). Statistical Yearbook of the Republic of Serbia 2010. Retrieved August 25, 2015, from http://istmat.info/files/uploads/47439/ statistical_yearbook_of_the_republic_of_serbia_2010.pdf

Statistical Office of the Republic of Serbia. (2011). Statistical Yearbook of the Republic of Serbia 2011. Retrieved August 25, 2015, from http://www.media.srbija.gov.rs/ medsrp/dokumenti/SGS2011_cyr.pdf

Statistical Office of the Republic of Serbia. (2012). Statistical Yearbook of the Republic of Serbia 2012. Retrieved August 25, 2015, from http://pod2.stat.gov.rs/ObjavljenePublikacije/G2012/pdf/G20122007.pdf

Statistical Office of the Republic of Serbia. (2013). Statistical Yearbook of the Republic of Serbia 2013. Retrieved August 25, 2015, from http://webrzs.stat.gov.rs/WebSite/ repository/documents/00/01/17/20/G20132010.pdf

Statistical Office of the Republic of Serbia. (2014). Statistical Yearbook of the Republic of Serbia 2014. Retrieved August 25, 2015 from http://pod2.stat.gov.rs/ObjavljenePublikacije/God/SGS2014.pdf

Turistički cvet. (2015). Vesti. Retrieved August, 29, 2015, from www.turistickisvet-hotnews.com

UHPA - Association of Croatian travel agencies. (2011). Taleb Rifai: Turističke agencije budućnosti. Retrieved August, 30, 2015, from http://www.uhpa.hr/clanak/talebrifai-turisticke-agencije-buducnosti-32993

UHPA - Association of Croatian travel agencies. (2013). Destinacijske menadžment kompanije. Retrieved August, 30, 2015, from http://www.uhpa.hr/publikacija/destinacijske-menadzment-kompanije

UNWTO, UN Joint Programme "Sustainable Tourism for Rural Deelopment". (2011). Strategy for Sustainable Rural Tourism Development in Serbia. In Master Plan for Sustainable Rural Tourism Development in Serbia. Madrid: UNWTO. Retrieved October 14, 2012, from http://www.turizam.merr.gov.rs /images/ stories/ UNWTO/Novi fajlovi 21042011/ VOLUME II STRATEGY for Sustainable Rural Tourism Development in Serbia_190411.pdf.

USAID. (2015). Destination Management Company Training Manual for USAID. Retrieved September 5, 2015, from http://pdf.usaid.gov/pdf_docs/Pnad1944.pdf

YUTA-Serbia National Association of Travel agencies. Retrieved August 30, 2015, from http://www.yuta.rs/en/ 